\title{
O PROBLEMA DA FUNDAMENTAÇÃO DA ÉTICA NA FILOSOFIA DE SCHOPENHAUER ${ }^{1}$
}

\author{
Jacqueline de Oliveira Moreira*
}

\section{RESUMO}

O presente artigo visa apresentar a concepção ética de Schopenhauer refletindo, primeiramente, sobre a ineficácia da razão no campo da moralidade. Para o filósofo o fundamento da ação moral está no sentimento da compaixão. E esse, por sua vez, só é possível mediante a percepção da verdade metafísica da unidade entre todas as coisas. Ultrapassando o véu de Maia do mundo fenomênico, através da abolição do egoísmo e negação da vontade individual, o homem encontra como princípio último do universo a Vontade, sendo que esse ato de abnegação desvela o verdadeiro princípio ético.

PALAVRAS-CHAVE: Schopenhauer. Moralidade. Vontade. Egoísmo.

\section{ABSTRACT}

This article aims to present Schopenhauer's ethical conception, reflecting, first of all, on the inefficiency of reason in the field of morality. To the philosopher, the foundation of the moral action lies in the feeling of compassion. This feeling, on the other hand, is only

1 Trabalho baseado na tese acadêmica: MOREIRA, Jacqueline de Oliveira. A negação da vontade: o problema da fundamentação da moral na filosofia de Schopenhauer, concluída em 1996.

* Doutora em Psicologia Clínica pela Pontifícia Universidade Católica de São Paulo e Professora da Pontifícia Universidade Católica de Minas Gerais. 
possible when the metaphysical truth and the union of all things is perceived. Going beyond Maya's veil of the phenomenical world, through the abolishment of selfishness and the denial of one's will, man founds out that the ultimate principle of the universe is the Will, and this act of abnegation leads to the true ethical principle.

KEYWORDS: Schopenhauer. Morality. Will. Selfishness.

\section{O papel da razão no âmbito da ética}

Segundo Schopenhauer, Kant, na Crítica da razão pura, utiliza a razão como um conceito dirigido para a técnica, enquanto na Crítica da razão prática "a razão se apresenta como a fonte e a origem da inegável significação ética da conduta humana [...]" (CFK, 1988, p. 165). ${ }^{2}$ A virtude, a nobreza de alma e a conduta ética seriam frutos da pura razão ${ }^{3}$. A razão aparece, neste ponto, como a única fonte possível da conduta puramente moral. No pequeno trecho abaixo, Schopenhauer define a moral kantiana da seguinte forma: "Agir racionalmente e virtuosa, nobre e santamente seria uma e mesma coisa: e agir egoisticamente, maldosa e viciosamente seria agir irracionalmente (CFK, 1988, p. 166).

Na opinião de Schopenhauer, apenas uma pequena parcela de eruditos alemães compreendem como sinônimos virtude e vida racional; todo o resto do mundo tende a separar os conceitos. Para

2 Com a intenção de facilitar as referências às obras de Schopenhauer utilizaremos as seguintes abreviaturas: $\mathbf{O}$ mundo como Vontade e Representação: MVR; Crítica da filosofia kantiana: CFK; Sobre o fundamento da moral: SFM.

3 Schopenhauer mais uma vez questiona a afirmação kantiana de liberação da ética dos móbiles materiais. A moral kantiana afirma a possibilidade do comportamento virtuoso apenas pela pura razão. Mas como o homem não é somente racional faz-se necessário recorrer à idéia de um imperativo categórico, um Dever Incondicionado, que para Schopenhauer é uma contradição, pois o conceito de Dever faz necessariamente referência a um castigo ou recompensa. Por este fato devemos desconfiar da afirmação de que Kant teria liberado a ética dos móbiles materiais. 
confirmar sua posição evoca a vida de Cristo. Certamente não existiu um homem mais virtuoso que Cristo, mas teria sido também o mais racional dos homens? Dificilmente pode-se denominar as ações de Cristo como o cume da racionalidade, pelo menos na visão schopenhaueriana. Um homem que se expõe a ponto de ser humilhado, assassinado cruel e covardemente não pode estar agindo racionalmente, ainda que seu comportamento seja virtuoso. $\mathrm{Na}$ perspectiva de Schopenhauer um cidadão que trabalha honestamente, ou mesmo um trapaceiro que tem em vista sua própria existência e sustento da família está agindo racionalmente. Percebemos que a concepção de Schopenhauer de racionalidade está vinculada à idéia de fina astúcia, de pleno domínio do exercício da razão para executar tarefas. Schopenhauer pergunta-nos se por acaso seriam irracionais as prescrições que o esperto, conseqüentemente, ponderado e perspicaz Maquiavel dá ao príncipe. A alusão a Maquiavel autoriza Schopenhauer a ligar maldade a razão, e a referência a Cristo possibilita a vinculação de nobreza de espírito a irracionalidade. Há um ataque incisivo à identificação feita por Kant entre razão e virtude; citando Rousseau, Schopenhauer afirma que a razão não pode ser sede dos impulsos morais. Vejamos a citação do Emílio presente no texto de Schopenhauer :

A razão nos engana, mas a consciência não engana nunca: é impossível explicar pelas conseqüências de nossa natureza o princípio imediato da consciência, independente da própria razão [...]. Meus sentimentos naturais falavam pelo interesse comum, minha razão referia tudo a mim [...]. Em vão se quis estabelecer a virtude somente pela razão, que base se pode dar-lhe? [...]. Em todas as questões de moral, como esta, achei sempre bom resolvê-las pelo dictamen de minha consciência mais do que pelas luzes de minha razão (CFK, 1988, p. 167).

Evocar a figura de Rousseau para atacar a identificação kantiana entre virtude e razão constitui uma estratégia bastante interessante, pois é conhecida a sua influência sobre Kant. Entretanto, não podemos esquecer que esta influência data do 
período pré-crítico e que se refere especialmente à idéia da "voz da consciência" e à idéia de "sentimento moral". Para além destes fatos, devemos enfatizar que Kant, mais tarde, irá divergir de Rousseau sobre os princípios reguladores da vida moral, que deixa de ser um sentimento para dar lugar à razão, ao dever e à lei moral.

Schopenhauer prossegue na sua investigação histórica sobre a relação entre razão e virtude. Agora busca no berço da cultura ocidental subsídios para confirmar a distinção entre razão e virtude. Aristóteles, na reconstrução de Schopenhauer (CFK, 1988, p. 167), nos diz que a virtude tem sua sede na parte da alma desprovida de razão e não na parte dotada de razão. Segundo Schopenhauer (CFK, 1988, p. 168), Cícero, filósofo romano que viveu nos anos de 106 a 43 a.C., afirma que a razão é o meio e o instrumento necessário para o crime.

A moral, a ação virtuosa, ultrapassa os limites da pura razão, portanto escapa do âmbito da educação. Schopenhauer mantém o pessimismo quanto à possibilidade de produzir - por meio da educação - pessoas virtuosas. Para ele a ética e a estética partilham de características comuns, pois não se pode ensinar nem a arte, nem a virtude, pois as duas categorias ultrapassam os limites da mera razão. Em suas próprias palavras, Schopenhauer nos diz:

A virtude não se aprende, não mais do que o gênio: quanto a ela, como quanto à arte, o saber por ele mesmo não tem valor; é um puro instrumento: resta saber manejá-lo. Além disso, bem loucos seríamos se contássemos com os nossos sistemas de moral para fazer homens virtuosos e nobres, santos: não menos loucos do que contar com a estética para criar poetas, estatuários e músicos (MVR, s.d., p. 358).

Schopenhauer vai ainda mais longe no seu pessimismo nos dizendo da impossibilidade prática de uma ética que efetivamente transformasse a humanidade. Em suas palavras:

[...] a procura de uma ética e de um princípio supremo dela, que tivessem influência prática e transformassem e 
melhorassem efetivamente o gênero humano, é exatamente o mesmo que a procura da pedra filosofal (CFK, 1988, p. 176).

Schopenhauer critica toda a ética prescritiva e condena toda a doutrina que assente a moral sobre conceitos abstratos, pois estes não podem deter "os fortes impulsos para a injustiça e manter o rigor do equilíbrio nem estar na base das censuras da consciência" (SFM, 1995, p. 102). A fundamentação da moral kantiana em idéias abstratas e a utilização de proposições sintéticas a priori no âmbito da moralidade são alvos da crítica schopenhaueriana a Kant.

$\mathrm{O}$ apriorismo, na filosofia teórica, refere-se às formas puras do tempo, espaço e causalidade que são funções de nosso intelecto, repousam em nossa consciência. Transpor o apriorismo do campo da filosofia teórica para o âmbito moral pode conduzir à falsa idéia de que o princípio moral expressa uma função do intelecto, ou repousa na consciência, portanto fundamenta-se na experiência interna. Dessa forma o princípio moral kantiano possuiria uma fundamentação antropológica. ${ }^{4}$ Pensamento infiel à doutrina kantiana, que insiste na ausência de fundamentação empírica para a moral, que insiste no apriorismo. Schopenhauer revela que o apriorismo na filosofia teórica tem seu campo de ação limitado ao mundo fenomênico. Da mesma forma, "também a suposta lei moral da filosofia prática, se surge 'a priori' na nossa cabeça, teria de ser apenas uma forma do fenômeno e deixar intocado o ser em si das coisas (SFM, 1995, p. 36)". Fato este que mostraria uma contradição interna no pensamento kantiano, pois Kant revela que a discussão moral se inscreve no âmbito do mundo numênico.

4 Ver SCHOPENHAUER, A. Sobre o fundamento da moral. São Paulo: Martins Fontes, 1995, p. 43- 49. Segundo Schopenhauer quase todos pós-kantianos se enganaram ao atribuir uma fundamentação na consciência para a moral kantiana. Reinhold teria cometido o erro ao dizer: "Kant tomou a lei moral como um fato imediatamente certo, como um fato originário da consciência moral". Nas palavras de Schopenahuier: "se Kant tivesse querido fundamentar empiricamente o imperativo categórico como fato da consciência, ele não teria deixado de, pelo menos, indicá-lo como tal".

Educ. e Filos., Uberlândia, v. 20, n. 40, p. 207-241, jul./dez. 2006. 
Kant desdenha toda experiência como "mola propulsora" (SFM, 1995, p. 46) da vontade. Em virtude disso, apenas restou como matéria da lei moral a pura forma, a universalidade. A discussão sobre o conteúdo da lei conduz-nos ao primeiro imperativo, que ordena, somente, que nossas ações subjetivas, ou as máximas, sejam de acordo com o dever e possam, assim, ser universalizadas. A ação puramente moral é aquela que pode tornarse universal, como no modelo das leis da natureza. A primeira fórmula do imperativo revela-nos o conteúdo que é a universalidade objetiva da lei. Segundo Schopenhauer, para Kant o homem deve chegar à idéia de uma lei moral de forma mágica, ${ }^{5}$ não se apresenta nenhum motivo efetivamente real para limitar a ação. O limite para a ação é a sua possibilidade ou impossibilidade de universalização. Mas qual será a instância julgadora? Para Schopenhauer, a motivação moral

[...] tem de ser algo positivamente agente e, portanto, real e, como para o homem só o empírico ou o que porventura é empiricamente existente tem realidade pressuposta, a motivação tem de ser, de fato empírica (SFM, 1995, p. 48).

Na concepção schopenhaueriana, os puros conceitos abstratos e a priori carecem de realidade e de efetividade possível, por isso não podem pôr em movimento as ações humanas.

5 Schopenhauer considera que a doutrina kantiana de uma razão prática autofundante e autodeterminante procede da psicologia racional, mais precisamente da idéia da alma, "ser originário e essencialmente cognoscente" (SFM, 1995, p. 60). Como "faculdade superior, a alma imaterial atuaria completamente por si mesma" (SFM, 1995, p.60). Por outro lado, a idéia de uma moral fundamentada unicamente em conceitos abstratos, na pura razão, revela o pensamento de que o ser íntimo e eterno do homem consiste na razão. Segundo Schopenhauer, "não se pode evitar a suspeita de que Kant teria aí pensado um pouco nos queridos anjinhos" (SFM, 1995, p. 35). A forma mágica da aparição do princípio moral kantiano, na crítica schopenhaueriana, se vincula aos aspectos acima citados. 
Schopenhauer conclui, assim, que o Imperativo Categórico não é um fato da consciência, pois o caminho antropológico foi vedado por Kant, mas também não é um fato da experiência externa. $\mathrm{O}$ dever absoluto não possui vínculo com a existência empírica. Dessa forma, na concepção de Schopenhauer, este princípio moral representa um substituto artificial da moral teológica. A forma imperativa é apenas uma inversão da moral teológica. Assim,

[...] esse disfarce teve de ser tão mais artificial e irreconhecível que o próprio Kant confiantemente enganou-se até a si próprio e pensou realmente estar estabelecendo os conceitos de mandamento e lei - que manifestamente só têm um sentido na moral teológica (SFM, 1995, p. 81).

E ainda mais, ao final de exposição da doutrina moral, Kant teria permitido a contaminação da "larvar moral teológica na doutrina do Soberano Bem $^{6}$ e nos Postulados da razão prática (SFM, 1995, p. 81)".

\section{O critério da ação moral}

Neste momento nos perguntamos sobre o critério que define uma ação moral para Schopenhauer. ${ }^{7}$ Entendemos que a intenção ética na filosofia de Schopenhauer não se relaciona com a busca

6 Schopenhauer insiste em denunciar como falso o formalismo moral kantiano. $\mathrm{O}$ argumento, agora, refere-se ao conceito de Soberano Bem, na perspectiva schopenhaueriana, esse conceito unifica, necessariamente, virtude e felicidade.

7 Sabemos que para Schopenhauer não será a felicidade o critério da ação moral, pois a virtude na sua essência íntima visa um objetivo oposto ao da felicidade individual. Virtude e felicidade são contrapostos, e mais, para Schopenhauer o Supremo Bem é uma petição de princípio, pois o bem é sempre relativo. Dessa forma, a discussão moral emerge na medida em que consideramos, primeiramente, o agente da boa ação na sua relação com o outro e, em seguida, no interior de si mesmo. 
mundana da felicidade. ${ }^{8}$ A felicidade relaciona-se com a satisfação plena da Vontade; mas este é um projeto impossível; o desejo é infinito, não se realiza em nenhum objeto. A atividade incessante da Vontade não encontra satisfação, nem repouso; é uma força demoníaca que faz com que o homem viva à deriva, oscilando de um lado para outro, tornando a sua vida um tormento.

Sabemos que, em linhas gerais, a reflexão sobre a existência histórica do homem encontra como uma das tarefas fundamentais a formulação e a elucidação de perguntas de caráter moral, já que a verdadeira dimensão humana se dá no âmbito das relações intersubjetivas. Sendo assim, é uma tarefa essencial investigar a possibilidade de convívio entre os homens, o que rege e garante a vida em comunidade. A discussão moral apenas se inscreve, ou seja, possui inteligibilidade e legitimidade no âmbito puramente humano das relações intersubjetivas. Segundo Herrero,

não podemos falar de ética sem que esta seja referida a uma comunidade, porque são justamente as relações intersubjetivas no seio de uma comunidade que são reguladas por leis éticas (1993, p. 89).

A situação da vida diária, o estar no mundo, coloca necessariamente o problema da ação. A situação prática pressupõe

8 Schopenhauer considera um grande mérito de Kant no campo da eticidade a crítica ao eudemonismo. Haveria duas possibilidades de ligação entre virtude e felicidade, ora seguindo o princípio de identidade, ora de acordo com o princípio de razão. Mas para Kant, a busca da felicidade refere-se a um principio prático, material, que revela a determinação de um móbile externo sobre a vontade. Portanto, a felicidade é um princípio inadequado para fundamentar a moralidade. Além disso, a felicidade é um principio que não porta a universalidade, é um princípio hipotético. Na verdade a razão não visa a felicidade; o instinto certamente obterá mais êxito na realização dessa tarefa. Assim, Kant teria banido o eudemonismo no campo da ética [Ver KANT, I. Fundamentação da metafísica dos costumes. São Paulo: Abril Cultural, 1974, p. 205a 207. (Coleção Os Pensadores).]. Entretanto, segundo Schopenhauer (SFM, 1995, p. 18), Kant haveria banido o eudemonismo de modo mais aparente do que efetivo. A Doutrina do Soberano Bem reintroduz a ligação entre virtude e felicidade. 
no mínimo dois termos: o sujeito da ação e o objeto que sofre a ação. A ação moral ou atitude prática moral refere-se ao comportamento de um sujeito em relação a um outro. A definição de uma ação moral tem, necessariamente, que levar em consideração o sujeito e o outro. A ação ética não está dirigida, num sentido primordial, para uma transformação do mundo natural, mas sim do mundo humano. Tudo que é humano colocará mais cedo ou mais tarde uma questão ética. Determinar, descrever o campo próprio da ética, ou estabelecer a estrutura mínima da conduta ética é examinar as relações entre os homens. Neste sentido o imperativo kantiano "[...] age de tal maneira que uses a humanidade, tanto na tua pessoa como na pessoa de qualquer outro, sempre e simultaneamente como fim e nunca simplesmente como meio" representa o núcleo celular do fenômeno ético, ou seja, a estrutura mínima na experiência vulgar do fenômeno ético é simbolizado pelo respeito à figura humana. $\mathrm{O}$ fato da alteridade é, propriamente falando, a questão da reflexão moral. Alteridade e altruísmo, palavras de mesma origem etimológica, são vocábulos fundamentais no universo ético. Egoísmo, amor próprio fazem contraposição à verdadeira conduta moral.

Schopenhauer compartilha a idéia de que a ação moral referese à atitude de um sujeito em relação a um outro. Para Schopenhauer, o único critério possível para definição de uma ação moral é a necessidade de realização do bem-estar de outrem.

Como vimos, na concepcão schopenhaueriana, é impossível fundamentar a ética repousando-a em conceitos abstratos, isto é, a pura razão não pode conter a força dos impulsos para a injustiça e crueldade. Mas existiria, então, uma moral natural, independente de qualquer criação humana, como a razão, a lei, o estado ou a religião? A resposta para tal questão deve ser buscada no trabalho de investigação das ações às quais atribuímos autêntico valor moral, que são a justiça espontânea, a pura benevolência e a piedade efetiva. Revelado o fundamento, as verdadeiras razões ou os motivos últimos subjacentes a estes fenômenos, desvelaremos, conseqüentemente, $\mathrm{o}$ fundamento da moralidade. Assim, segundo Schopenhauer, seria o caso, primeiro, de resolver a questão empírica: encontramos 
realmente na experiência ações de justiça espontânea, benevolência desinteressada e caridade efetiva? O problema em questão não pode ser solucionado de modo puramente empírico, pois a experiência nos fornece apenas a ação, os motivos não são evidentes. Existe sempre a possibilidade de que um motivo egoísta determine a ação boa. Como saída dessa aporia, Schopenhauer apela para o bom senso: "[...] se alguém persistisse em negar a ocorrência de tais ações, então a moral segundo esse alguém seria uma ciência sem objeto real [...]" (SFM, 1995, p. 123-124).

Evidente que a moral não é uma quimera; as ações morais existem, apesar de estarem incluídas no âmbito das coisas inesperadas, das raras exceções. Schopenhauer nos diz: "Há de fato pessoas verdadeiramente honestas, como há realmente trevos de quatro folhas (SFM, 1995, p. 108)". Trágico! A existência de condutas morais é um fato inegável, mas raro, e até mesmo sobrenatural, tanto quanto o fenômeno da sorte. Schopenhauer cita uma passagem de Hamlet: "ser honesto, no estado em que está o mundo, é ser um homem escolhido em dez mil" (SFM, 1995, p.109). Por mais raras que sejam estas ações, a justiça, a benevolência e a caridade, serão estas as únicas a que se poderá atribuir um valor propriamente moral. Podemos considerar como denominador comum a essas ações a ausência de motivação egoísta. Assim, Schopenhauer anuncia: "A ausência de toda motivação egoísta é, portanto, o critério de uma ação dotada de valor moral" (SFM, 1995, p. 124).

As ações morais não são quimeras, e mais, o critério para definir uma ação moral é a ausência de motivação egoísta. Cabe, agora, investigar o que pode mover os homens a este tipo de ação. Primeiramente, devemos saber que nenhuma ação pode acontecer sem motivo suficiente. Segundo que a vontade é movida principalmente por um motivo que se refere ao seu bem-estar ou mal-estar, ou seja, que está de acordo ou contra uma vontade. Conseqüentemente, a ação tem por fim último o bem-estar ou o mal-estar. Toda ação cujo fim último é o bem-estar ou mal-estar do próprio agente é uma ação egoísta. Como já mencionamos, toda ação refere-se a um agente e a um outro, que participa da ação 
passivamente. Fácil concluir que a significação da ação moral só pode estar na relação com o outro. A Ação moral será aquela que visa o bem-estar ou a supressão do mal-estar de um outro. $\mathrm{O}$ agente da ação moral "só tem diante dos olhos o bem-estar ou supressão do mal-estar de um outro e nada almeja a não ser que aquele outro permaneça são e salvo ou receba ajuda, assistência e alívio" (SFM, 1995, p. 128). A ação moral possui uma finalidade altruística. O bem-estar e o mal-estar do outro é imediatamente o motivo da ação moral. Mas como é possível que o bem-estar de um outro mova a minha vontade? Como posso esquecer de mim mesmo, do meu bem-estar em prol do outro? O que permite a ultrapassagem da diferença total entre o eu e o outro? Vale dizer que essa diferença é fruto do princípio de individuação e fonte de todo o egoísmo. Schopenhauer nos responde que é apenas na identificação com outro que suprimimos a diferença, mas na verdade o outro não é, e nunca foi, uma exterioridade absoluta. A diferença é apenas fenomênica.

Assim, a condição de possibilidade do fenômeno moral é a dissolução do véu de Maia, a ultrapassagem do princípio de individuação e a conseqüente abolição do egoísmo. Podemos perguntar por que o egoísmo inteligente não é preferível à compaixão e por que a verdade metafísica demonstra a inferioridade do egoísmo.

\section{Para além do véu de Maia /A abolição do egoísmo}

Não parece impertinente relembrar que na metafísica da Vontade o nosso corpo é o ponto de partida, a chave que desvela o enigma metafísico do mundo. O corpo, enquanto vontade encarnada, converte-se no princípio fundamental de toda metafísica, pois se nos revela como Vontade e Representação. Mas se por um lado a experiência de nosso próprio corpo é a chave inicial que desvela o enigma metafísico do mundo, de outro, para poder contemplar esse espetáculo universal da Vontade, temos que dissolver o vínculo com o nosso próprio corpo. Tanto na atividade estética quanto na ética, o sujeito do conhecimento deve esquecer 
de seus interesses individuais para ultrapassar o véu do princípio de individuação e, assim, alcançar o conhecimento metafísico e tornar-se um sujeito puro, ou seja, liberto de vontade. $\mathrm{O}$ abandono do conhecimento racional, ligado ao abandono da individualidade constitui as condições para a dissolução do princípio da individuação e conseqüente abolição do egoísmo. Nesse estado, o indivíduo não está preso aos seus desejos e interesses egoístas. A diferença entre o eu e o outro é suprimida. O espaço, o tempo e a lei da causalidade, que determinam o princípio de individuação, que traduzem uma mesma e única Vontade numa multiplicidade de objetos perdem a força diante da contemplação estética e da conduta ética. A barreira entre o eu e o outro foi vencida, a ilusão desfeita. Só aqueles que são cativos do princípio da individuação e do egoísmo insistem na diferença entre o eu e o outro.

Sabemos que tanto a contemplação estética quanto a conduta moral pressupõe a dissolução do véu de Maia, ou seja, a percepção intuitiva da unidade radical entre os seres. No entanto, a discussão estética não visa diretamente o problema do convívio ético entre os seres. A relação entre o eu e o outro, o problema da alteridade e da boa ação em relação a outrem, não é uma questão primordial na metafísica do Belo de Schopenhauer. Estamos cientes de que na contemplação estética serão os sentimentos do belo e do sublime a força propulsora para a ultrapassagem do princípio de individuação. Mas, e na problemática ética, o que impulsiona o sujeito na direção da dissolução do Véu de Maia? A resposta é simples: O sujeito nega sua individualidade e ultrapassa o Véu de Maia ou a partir do conhecimento intuitivo do sofrimento inerente à vida, ou através do sofrimento imediato, diretamente sentido. Será o sofrimento, a falta, o desamparo, que despertará em nós o sentimento de filiação ao outro. Só na dor nos compadecemos uns dos outros. Schopenhauer cita Rousseau, em Emílio (livro 4): "Primeira máxima: não é próprio do coração humano pôr-se no lugar de pessoas que são mais felizes que nós, mas somente daqueles que são mais dignos de pena etc" (SFM, 1995, p. 131).

Apenas o sofrimento e a dor são capazes de nos livrar do nosso egoísmo colossal. O homem é solidário, principalmente, nas 
situações de sofrimento, nas tragédias. A dor é o salto, o impulso necessário para se ultrapassar o véu de Maia. O sofrimento constitui a mediação, o termo médio que possibilita a passagem da ilusão fenomênica para a verdade metafísica. O homem que sofre, ou que percebe sinceramente o sofrimento do outro, comumente quase não pensa em sua representação teatral cotidiana, se esquece de seus pequenos desejos.

A problemática moral coloca-nos uma condição sine qua non: uma ação moral deve visar o bem-estar do outro, a ilusão do princípio de individuação deve ser desfeita. O altruísmo moral prega a virtude da amizade e compaixão sem especificar a nacionalidade, a religião, a raça e nem mesmo a posição na escala animal do outro a ser respeitado. O princípio do altruísmo é uma abertura infinita que desvela a unidade radical entre os seres. Cabenos, agora, explicitar que Schopenhauer pensa em uma gradação nesse comportamento altruísta, que envolve a justiça, a generosidade e a caridade.

\section{A tripla gradação: justiça, benevolência e caridade}

Os três comportamentos em questão, que são considerados fenômenos morais, possuem uma raiz comum, qual seja, a abolição do egoísmo e a dissolução do véu de Maia. Para o homem justo, benevolente e caridoso o véu de Maia é transparente, a ilusão do princípio de individuação dissipou-se, não há diferença entre o eu e o outro.

A justiça nasce em uma inteligência capaz de perceber o véu do princípio de individuação. $\mathrm{O}$ homem justo não afirma sua vontade para além dos limites do seu próprio corpo, percebe que não está imune ao mal infligido a outrem. Mas o homem simplesmente justo contenta-se apenas em não infligir mal aos outros. Ele percebeu a ilusão do princípio de individuação, mas ainda está preso à sua personalidade. $O$ primeiro grau de efetivação do comportamento ético é negativo, isto é, contenta-se em não infligir o mal. Mas este já é um passo muito importante, pois "Originariamente somos todos inclinados para a injustiça e a 
violência, porque nossa necessidade, nossos apetites, nossa ira e nosso ódio aparecem imediatamente na consciência [...]" (SFM, 1995, p. 135); nossa individualidade e egoísmo possuem mais força sobre nossas almas. A máxima da justiça é "não prejudiques a ninguém" [Neminem laede]. O justo vê para além do princípio de individuação, percebe-se em pé de igualdade com o outro, por isso não lhe faz mal. No entanto, encontramos no homem justo o firme propósito de afirmar sua própria vontade, sem ultrapassar os limites do seu próprio corpo. O homem justo conserva a sua individualidade, por conseqüência respeita o outro sem autosacrifício. Estabelece uma relação de troca com o outro; dá o equivalente daquilo que tiver recebido dele. A justiça, como já vimos, nasce em uma inteligência capaz de perceber através do princípio de individuação; mas, se esta inteligência não parar nesta percepção e considerar cada vez mais os outros, se preocupando cada vez menos consigo, teremos, então, a benevolência ou generosidade de alma. No homem generoso o "[...] seu coração se dilata para além dos limites da sua individualidade; ele abandona a excitação ansiosa que a nossa própria conservação provoca, para ganhar a serenidade e até a alegria" (PERNIN, 1992, p. 170). O homem generoso, benevolente, atua positivamente em favor dos outros. Arremessa-se para o outro com um impulso atento e espontâneo, que não possui nenhum interesse antecedente, fundase no próprio ato da doação, não há nenhuma intenção egoísta subjacente. A generosidade, a benevolência, marca o limite extremo da gratuidade. O reconhecimento do meu próprio ser sob a aparência do outro permite que eu o ame gratuitamente. A benevolência desenvolvida se transformará em caridade. Retomando: o homem justo é aquele que vê através do princípio de individuação, mas insiste em manter os limites de sua individualidade; o homem benevolente será aquele de coração bom, que manifesta um amor desinteressado para com o outro, arremessa-se na direção do outro, mas seu altruísmo tem um limite, sua ação não deve possuir o risco de mortificação do próprio eu, ou seja, "[...] não há razão para preferir a pessoa do outro à nossa" (MVR, s./d., p. 498). Por fim, temos a caridade, que é considerada 
por Schopenhauer, no texto Sobre o fundamento da moral, como a segunda virtude. Schopenhauer irá realizar uma ligação indissolúvel entre caridade e piedade. "Toda caridade pura e sincera é piedade, e toda a caridade que não é piedade é apenas amor próprio" (MVR, s./d., p. 499). A ligação entre caridade e piedade aparece como resposta para a seguinte pergunta: "O que é que, então, nos pode inspirar a praticar boas ações, atos de caridade?" (MVR, s./d., p. 499). A resposta é direta: será o compadecimento pelo sofrimento alheio o impulso para a boa ação. Nesse ponto Schopenhauer é explicitamente contrário a Kant. Para o último, a verdadeira boa ação nasce do Dever e do Imperativo, portanto de um pensamento abstrato. Schopenhauer acredita que o conceito é impotente no que tange à problemática da produção de boas ações. O que inspira a prática das boas ações, dos atos caridosos é o conhecimento do sofrimento alheio. A caridade faz alusão implícita a um viver-para-ti, a um lançar-se intenso em direção ao outro. E neste sacrifício mortal o sujeito toca a eternidade do princípio metafísico. Justiça, benevolência, caridade, sacrifício e coragem são algumas palavras que constituem o vocabulário prático da moral schopenhaueriana. Viver uma existência verdadeiramente moral, ou continuamente moral talvez seja uma tarefa para ascetas e/ou santos.

A caridade e a piedade apresentam uma importância crucial na filosofia de Schopenhauer, uma vez que o sofrimento é a própria essência da vida, querer fazer o bem ao outro, compadecer-se pelo sofrimento alheio é propor uma ação no cerne da existência. Parecenos importante alertar que compadecer-se pelo sofrimento alheio não é viver a dor do outro, mas sim com o outro. Essa ação pressupõe uma identificação entre o eu e o outro, ou seja, pressupõe a ultrapassagem da barreira ilusória que separa o eu do não-eu. Para Schopenhauer, a caridade é uma virtude mais feminina, pois fala diretamente à intuição e pressupõe um maior poder de compaixão. Em contrapartida, a justiça é uma virtude mais masculina, pois necessita de um autodomínio racional, que é mais familiar aos homens. A intensa vida racional torna os homens aptos para entender, manter e tomar como normas princípios gerais. A 
conclusão que podemos tirar dessa contraposição nas relações de gênero é que no âmbito da virtude de justiça o conhecimento abstrato desempenha um papel mais importante do que nas virtudes de caridade. Se a máxima da virtude de justiça é "Não prejudiques a ninguém [Neminem laede]; na virtude da caridade a máxima consiste em: Ajuda a todos quanto puderes. Assim, o principal princípio da ética é a regra: 'Neminem laede, imo omnes, quantum potes, iuva!' [Não prejudiques a ninguém, mas ajuda a todos quanto puderes]".

Resta-nos dizer que este amor que tem como origem uma intuição capaz de ultrapassar o princípio de individuação nos conduz à libertação dos desígnios da vontade e nos libera da escravização dos desejos infinitos. Parece claro que será o sofrimento, a dor, o impulso básico para a dissolução da barreira que existe entre o eu e o outro. Mas, segundo Schopenhauer, esse é um processo misterioso, 9 "é algo de que a razão não pode dar conta diretamente e cujos fundamentos não podem ser descobertos pelo caminho da experiência" (SFM, 1995, p. 155), ainda que seja algo cotidiano. Schopenhauer está no momento preparando "terreno" conceptual para introduzir a idéia da compaixão como único fenômeno explicativo do sentimento de identificação entre o eu e o outro, mediado pela percepção do sofrimento.

\section{Compaixão: ${ }^{10}$ o único fundamento moral válido}

Para Schopenhauer existem três classes superiores de motivos que determinam as ações humanas: a) o bem próprio; b) o sofrimento alheio e c) o bem alheio. A primeira classe representa o

9 Sobre a consideração schopenhaueriana da compaixão como um mistério conferir SCHOPENHAUER, A. O mundo como Vontade e Representação. Porto: Rés, p. 129, 133 e 155.

${ }^{10} \mathrm{O}$ termo em alemão para compaixão é Mitleid, composto pela preposição mit que significa "com" e pela palavra leid, derivada do verbo leiden que significa "sofrer". O significante Paixão em alemão, Leidenschaft, também é derivado de leiden. 
egoísmo colossal, grande fonte das condutas humanas. A crueldade e a maldade expressam a segunda classe de motivos. Por último, teremos a compaixão, reduto por excelência da realização efetiva da moralidade. A compaixão é aquela ação que visa unicamente o bem alheio, sem nenhum interesse egoísta subjacente. É uma generosidade e caridade desinteressada, "[...] ajudo ao outro para tirá-lo da sua necessidade e dificuldade e por querer sabê-lo livre de seu sofrimento - e nada além disso" (SFM, 1995, p. 154). O fim último de minha vontade é o outro. Sinto-me gratificado ao ajudálo gratuitamente. Cabada aponta para uma questão bastante pertinente: o sistema ético schopenhaueriano estaria realmente livre do egoísmo? (CABADA, 1991, p. 388). Se consideramos que a compaixão, fundamento da ação moral, exige uma relação de identificação com o outro, que na verdade não é uma exterioridade absoluta, mas um duplo do próprio eu, pode-se identificar um traço egoísta na compaixão. Assim, a crítica schopenhaueriana a Kant, que revela um móbile material, um egoísmo racional no imperativo categórico, “[...] age de tal modo que a máxima de tua vontade possa sempre valer, ao mesmo tempo, como princípio de uma legislação universal", pode ser aplicada ao próprio Schopenhauer.

Mas como posso querer imediatamente o bem do outro? Isso pressupõe necessariamente que eu sofra com seu mal-estar, e que compartilhe de seu bem-estar, ou seja, que eu me identifique com ele, que a barreira que nos separa seja ultrapassada. Segundo Schopenhauer, o processo que possibilita tal ação

[...] não é sonhado ou apanhado no ar, mas algo real e de nenhum modo raro: é o fenômeno diário da compaixão, quer dizer a participação totalmente imediata, independente de qualquer outra consideração, no sofrimento de outro e, portanto, no impedimento ou supressão deste sofrimento, como sendo aquilo em que consiste todo contentamento e todo bem-estar e felicidade (SFM, 1995, p. 129).

Neste ponto Elósegui faz uma objeção bastante pertinente: Schopenhauer parece cair numa aporia, pois a compaixão, 
fundamentada na unidade entre os seres, tende a unir o seres conscientemente, mas a identidade só existe inconscientemente (ELÓSEGUI, 1989, p. 82-83). E mais, como podemos conhecer o outro diretamente "[...] se previamente afirmou-se que conhecemos os demais indiretamente, mediante a representação deles em nosso cérebro?" (ELÓSEGUI, 1989, p. 86).

Schopenhaeur não enfrenta diretamente esses problemas, tenta uma saída ${ }^{11}$ dizendo que a compaixão é um fenômeno diário, um fato da experiência. Mas, estaria Schopenhauer buscando o fundamento da moral na experiência cotidiana? Essa atitude de Schopenhauer, de adotar o procedimento analítico é justificada na seguinte citação:

A partir de uma metafísica dada e admitida como verdadeira atingir-se-ia o fundamento da ética pelo caminho sintético; assim, este seria construído a partir de baixo, e, conseqüentemente, a ética apresentar-se-ia apoiada firmemente. Em contrapartida, com a separação, posta nesta tarefa como necessária, entre ética e a metafísica, nada mais resta senão o procedimento analítico, que parte dos fatos, quer da experiência externa, quer da consciência (SFM, 1995, p. 8).

Schopenhaeur deduz a compaixão a partir de três passos fundamentais:

${ }^{11}$ Outra saída possível seria a revitalização do conceito de consciência melhor. Segundo Cacciola, nos "Manuscritos de 1813, Schopenhauer estabelece a duplicidade da consciência de si, que se manifesta na consciência empírica e na consciência melhor (besseres Bewusstsein) (106)". As duas consciências estariam conectadas no mesmo eu, sendo que a consciência melhor "indica uma forma de consciência superior, uma autonomia da virtude diante da ilusão do conhecimento fenomênico que é determinado por meio do entendimento e da razão" (107). Esta noção não aparece no Mundo como Vontade e Representação, mas este conceito parece-nos uma possibilidade de resposta para a questão de Elósegui, pois podemos intuir a unidade entre os seres porque possuímos uma dupla consciência: uma consciência empírica que está presa às formas da representação; e uma consciência melhor que goza de autonomia em relação às formas do mundo representado. 
1. “O próprio da ação, positiva ou negativa, moralmente boa, [é] ser dirigida tendo em vista a vantagem e o proveito de outrem" (SFM, 1995, p. 128).

2. “Ora, para que minha ação seja executada unicamente tendo em vista outrem, é necessário que o bem desse outrem seja para mim, e de maneira direta, um motivo, tanto quanto meu bem o é, de ordinário" (SFM, 1995, p. 128).

3. "Ora, é supor que por um meio qualquer eu me identifico com ele, que qualquer diferença entre mim e outrem está destruída, pelo menos até certo ponto, pois é justamente nessa diferença que repousa meu egoísmo" (SFM, 1995, p. 129).

Todo esse movimento torna-se inteligível apenas por intermédio do fenômeno da compaixão. Podemos questionar o processo de dedução da compaixão quanto à fidelidade ao procedimento analítico, pois parece-nos que a discussão metafísica desempenha um papel de um a priori. Mas, por outro lado, a utilização, por parte de Schopenhauer, de exemplos empíricos funciona como uma atenuante para essa desconfiança. Schopenhaeur teoriza o menos possível. Cita, relata, explora biografias e a vida de santos. Segundo Pernin, "Schopenhaeur quer seguir o fio da experiência" (PERNIN, 1992, p. 167). Toma o exemplo de Caio e Tito, personagens que abdicam do assassinato de um rival, que desistem de matá-lo sem um motivo explícito. Em um exercício de especulação, Schopenhaeur, baseando-se nas doutrinas de Kant, Fichte, Wolff, Spinoza e outros, propõe razões para o comportamento de Caio. Pensando como Kant, Caio diria:

Eu pensei que a máxima de meu procedimento neste caso não teria sido adequada a dar uma regra universalmente válida para todos os possíveis seres racionais, pois eu teria tratado meu rival só como meio e não, ao mesmo tempo, como fim (SFM, 1995, p. 158).

Refletindo um pensamento spinoziano, Caio diria: “Nada é mais útil para o homem que o próprio homem, logo, eu não poderia matar um homem" (SFM, 1995, p. 159). A proposta 
schopenhaueriana é reservada para explicar as razões de Tito. Este, por um ato de compaixão e misericórdia, não pode matar o rival, pois suprimida a diferença entre ele e o outro, no caso, o rival, o mal infligido a este último atingiria o primeiro (Tito). Após esse exercício especulativo, Schopenhauer pergunta: Entre Caio e Tito qual deles é o melhor homem? Os dois abdicaram do assassinato. As razões que conduziram Caio à desistência encontram-se nos pensamentos de Kant, Spinoza e outros. Tito abandonou a vingança e o desejo de assassinato pela compaixão. Schopenhauer interroga o leitor, visando, assim, conduzí-lo para uma maior aceitação da ética da compaixão, mostrando que o único princípio moral que em verdade aponta para dignidade humana é a compaixão. "Quem foi impelido por um motivo mais puro? Nas mãos de quem poria de melhor grado o seu destino?" (SFM, 1995, p. 159).

Outra maneira de confirmar a existência empírica do fenômeno da compaixão é por meio do assombro diante do horror da crueldade. Schopenhaeur nos diz que diante de um ato cruel não nos perguntamos como é possível a existência de um princípio subjetivo que não possui condição de se tornar um princípio objetivo, ou seja, universal. A nossa pergunta revela a perplexidade diante de uma ausência de compaixão.

Devemos dizer que a compaixão é mais evidente na virtude de caridade do que na virtude de justiça. $\mathrm{O}$ homem justo se limita à afirmação de sua vontade dentro dos seus domínios. O homem caridoso não distingue entre o bem-estar do outro e o seu próprio bem-estar. Seria, então, a virtude de caridade a verdadeira virtude moral? Segundo Schopenhauer, "[...] a justiça é pois a primeira e fundamental virtude cardeal" (SFM, 1995, p. 151). Os filósofos em todos os tempos consideraram a justiça, mas a caridade - que sempre existiu prática e faticamente - nunca foi objeto de reflexões filosóficas. Sendo assim, Schopenhauer propõe como contribuição pessoal para a história da ética fundamentar filosoficamente, ou seja, pensar abstratamente, um sentimento comum como fundamento da conduta moral. Schopenhauer anuncia que apenas Rousseau o precedeu, era o único a pensar na compaixão como fundamento da moral. Nas palavras de Schopenhauer: "[...] minha fundamentação tem 
por ela a autoridade do maior moralista de toda a época moderna: esta é, sem dúvida, Jean-Jacques Rousseau [...]" (SFM, 1995, p. 175).

Para Rousseau, a piedade é um sentimento natural que apoia a razão, moderando, assim, o egoísmo e a crueldade entre os indivíduos. Todas as outras virtudes decorrem deste sentimento natural. Segundo Rousseau, seria devido à "repugnância inata em ver seu semelhante sofrer" (SFM, 1995, p. 176) que o homem age moralmente. Segundo Schopenhauer, no pensamento oriental e até mesmo em Atenas a compaixão ocupa um lugar privilegiado. “Um dito de Phokion que nos foi conservado por Stobeu apresenta a compaixão como o mais sagrado no homem: 'não se deve tirar o altar do templo, nem a compaixão da vida humana" (SFM, 1995, p. 180).

Mas esse reconhecimento da compaixão não impossibilita a objeção quanto ao poder de universalização desse fundamento. Schopenhauer, na operação de defesa desta acusação, diz que a compaixão é um fato inegável da consciência humana, não repousa em conceitos, dogmas, educação ou religião, propriedades humanas mutáveis. Além disso, a compaixão é ilimitada, não se restringe ao reduto das relações humanas. A compaixão genuína estende-se aos animais. Para Schopenhauer é impossível negar a existência da manifestação verdadeira da compaixão mesmo nas situações históricas mais cruéis. Mas, se esta objeção é facilmente afastada, pode-se levantar outra, qual seja, contestar o pretenso desinteresse da compaixão, afirmando que compadecer-se pelo mal do outro e agir visando o seu bem é, em última instância, prever a própria desgraça e almejar auxílio futuro. Objeção delicada, seguindo o exemplo de Kant, podemos indagar se existe realmente uma ação puramente moral, sem nenhuma impureza de amor-próprio. Kant se abstém da resposta,

[...] na realidade, é absolutamente impossível encontrar na experiência com perfeita certeza um único caso em que a máxima de uma ação, de resto conforme ao dever, se tenha baseado puramente em motivos morais e na representação do dever [...] não se pode concluir com segurança que não tenha sido um impulso secreto de amor-próprio (1974, p. 213). 
A razão independe do fenômeno, o dever é anterior a toda experiência e reside na idéia de uma razão pura que determina a vontade aprioristicamente, mesmo que na prática não aconteça. O problema de Kant, no início da construção de sua doutrina moral, não é a efetivação ou aplicação de sua doutrina moral, mas sim encontrar leis morais que sejam universais, leis que tenham valor para todos os seres racionais em geral, não só sob condições contingenciais, mas sim de modo absoluto e necessário. Torna-se então evidente que nenhuma experiência pode fornecer motivos nem sequer para evidenciar a possibilidade dessas leis, cuja origem só pode ser a priori na pura razão prática. Os conceitos de dever, ação moral e boa vontade são idéias que a razão tece a priori do ideal de perfeição moral. Para Kant, em uma filosofia prática, “[...] não temos de determinar os princípios do que acontece, mas sim as leis do que deve acontecer" (1974, p. 228), quer dizer, determinar a priori os princípios do dever.

Schopenhauer, para provar que é possível encontrar no mundo uma ação puramente moral, ou seja, uma ação fundamentada na compaixão, evoca a vida de Jesus e dos ascetas hindus. Será com a especificação e elucidação do conceito de negação da Vontade que Schopenhauer apresentará a prova conceptual e, concomitantemente, empírica da existência da ação puramente moral, isto é, da pura compaixão. A compaixão será comprovada a nível abstrato, dentro do sistema schopenhaueriano com o conceito de negação da Vontade e, a nível empírico, com a exemplificação do ascetismo em alguns homens, no decorrer da história.

Em Schopenhauer, a compaixão goza de um duplo estatuto: de um lado, é um fenômeno cotidiano, representa a forma como a moral se faz presente no mundo da vida; de outro, a compaixão é o princípio da moralidade, é o fundamento da ética, é o princípio a partir do qual toda ação moral procede. Há uma coincidência nos termos, mas devemos ficar atentos para esse duplo uso do significante compaixão.

Uma vez revelada a essência, o fundamento da moralidade, e confirmada a existência de tal fundamento, cabe-nos, agora, 
articular esse fundamento com a metafísica, explicação última e verdadeira da existência em geral. Schopenhauer cita Wolff: "As trevas na filosofia prática não se dissipam se a luz da metafísica não as ilumina" (SFM, 1995, p. 7). Cita, também, Kant: “A metafísica deve preceder, e, sem ela, não pode haver nenhuma filosofia moral" (SFM 1995, p. 7). Para Schopenhauer, seja qual for o fundamento ético, este deve apoiar-se e ter suas bases em alguma metafísica. $\mathrm{Na}$ verdade, Schopenhauer, ao elucidar o fenômeno da compaixão, diz que este se funda na superação da diferença entre o eu e o outro, ou seja, na percepção intuitiva da identidade radical entre os seres. Quer dizer, a chave para decifrar o enigma da compaixão é a metafísica da Vontade. É a dissolução da manifestação fenomênica do princípio da individuação. Segundo Alain Roger (1995, p. LVII), Schopenhauer anuncia a articulação entre o fundamento da ética e o fundamento metafísico em três observações. Primeiro, a compaixão é revestida de um mistério que escapa aos domínios da razão. Schopenhauer diz:

Certamente este processo é digno de espanto e até mistério. É, na verdade, o grande mistério da ética, seu fenômeno originário e o marco além do qual só a especulação metafísica pode arriscar um passo (SFM, 1995, p. 129-130).

A explicação do fenômeno da compaixão é demasiadamente importante, mas somente metafisicamente encontraremos tal explicação. Schopenhauer insiste:

Este processo é, eu repito, misterioso, pois é algo de que a razão não pode dar conta diretamente e cujos fundamentos não podem ser descobertos pelo caminho da experiência. E, no entanto, é algo cotidiano (SFM, 1995, p. 155-156).

A compaixão, além de ser um fenômeno cotidiano, é, também, universal, por isso Schopenhauer dedica uma longa passagem à discussão da proteção dos animais (SFM, 1995, p. 167 a 174). Na opinião do filósofo, só um cego, em todos os sentidos, não reconhece 
que o essencial e o principal no animal é da mesma matéria que o essencial no homem, ou seja, a Vontade é o princípio subjacente a todos os seres. Por fim, a terceira observação que nos permite vincular moral e metafísica é a dúvida quanto à fidelidade ao procedimento analítico na dedução da compaixão. Schopenhauer, no trabalho de compreensão da compaixão, utiliza-se da fórmula do Veda "Tat-twan-asi" ("Tu és isto"). O homem compassivo é aquele que libertou-se do princípio de individuação, que compreendeu a unidade radical entre os seres. Este sujeito suavizou seu estado de enfermidade metafísica. A imbricação entre metafísica e ética na filosofia schopenhaueriana representa um tema que merece maior exploração, mas, no momento, dedicaremos nossa atenção à elucidação e discussão do tema da negação da vontade.

\section{Negação da vontade}

A negação da vontade pertence, como a justiça, a compaixão, a identidade entre todos os seres, enfim como a moralidade, à dimensão da coisa em si. As virtudes morais como a justiça e a compaixão referem-se, juntamente com a negação da vontade, ao mundo numênico, enquanto que a multiplicidade dos seres, o individualismo, o egoísmo e a crueldade agrupam-se nos domínios do mundo fenomênico. Schopenhauer propõe, em sua ética, reconduzir o homem enfermo, imerso no mundo fenomênico, à sua origem, à percepção da identidade entre todos os seres, em uma palavra, reconduzir o homem ao mundo numênico. Nesse trabalho, Schopenhauer irá utilizar-se amplamente do pensamento oriental, das religiões asiáticas mais antigas e também do cristianismo. O núcleo de toda referência à vida de Cristo, de Buda e dos santos e ascetas está no reconhecimento de que toda a salvação e libertação possível consiste na negação da vontade.

Explicitando a relação entre moralidade e negação da vontade, podemos dizer que o indivíduo justo ou caridoso é aquele que vê através do véu do princípio da individuação, é aquele que não faz diferença entre o eu e o outro, que é capaz de abdicar de todos os seus desejos pelo outro. Pois esse sujeito 
[...] percebe o conjunto das coisas, conhece-lhes a essência, e vê que ela consiste num escoamento perpétuo, num esforço estéril, num contradição íntima, e num sofrimento contínuo; e ele vê que é a isso que estão votados, a miséria humana e a miséria animal (MVR, s./d., p. 503).

Aquele indivíduo prisioneiro do princípio da individuação e do egoísmo conhece apenas coisas individuais e as utilidades destas para sua personalidade auto-centrada. Esse enfermo metafísico desliza de objeto em objeto buscando a satisfação, sem perceber que todos os objetos oferecidos à sua vontade insaciável, em essência, são iguais. Encontrando sempre um motivo novo, que seduz momentaneamente sua vontade, esse infeliz se faz prisioneiro da miséria, do sofrimento e da falácia múltipla do mundo fenomênico. Enquanto o conhecimento do todo, a percepção intuitiva da unidade radical entre os seres liberta o homem da falácia dos desejos, propiciando um calmante para a vontade. O sujeito que ultrapassou o véu do princípio da individuação sabe que a fonte de todo mal e sofrimento e mesmo da busca frenética por satisfação está no mundo fenomênico, está na ilusão da diferença. Então, esse sujeito desliga-se da vida, dos desejos infinitos e dos prazeres momentâneos. Neste estado de abnegação voluntária, de resignação, a calma verdadeira toma conta da alma, pois não há mais uma luta frenética da vontade contra si mesma, ela já não se afirma. Nas palavras de Schopenhauer:

A sua vontade dobra-se: ela já não afirma a sua essência, representada no espelho do fenômeno; ela nega-a. O que evidencia esta transformação é a passagem da virtude ao ascetismo que o homem executa nessa altura (MVR, s./d., p. 504).

Para o indivíduo que percebeu a verdade, já não lhe basta simplesmente amar os outros como à sua pessoa; nasce nele um desgosto contra a vontade de viver, contra a falácia do mundo 
fenomênico; a vontade passa a ser negada. Negação da vontade não é outra coisa senão

[...] a resignação ou a santidade absoluta, [que] resulta sempre daquilo que acalma o querer, isto é, a noção do conflito da vontade consigo mesma e da sua futilidade radical, futilidade que se exprime nos sofrimentos de todos os homens (MVR, s./d., 526).

A negação da vontade pode ser representada pela renúncia voluntária, pela resignação, pela total ausência de vontade no ser vivo. Esta redenção proposta por Schopenhauer é questionada por Ávila: "Estranha redenção é esta que consiste em algo parecido a uma morte em vida" (ÁVILA, 1989, p. 73). Para responder à questão de Ávila, poderíamos pensar numa aproximação entre a supressão da Vontade proposta por Schopenhauer e o vazio proposto pela religião budista. Mas, segundo Antonio Palao (1990, p. 215), o pensamento budista não propõe a supressão do sofrimento, propõe a aceitação da transitoriedade do mundo. O Budismo enfatizou a transitoriedade de todas as coisas, inclusive do "eu". Mas, não podemos esquecer que o ascetismo, prática budista, propõe a emancipação espiritual obtida pela exterminação da dor graças à eliminação de todo o desejo: "Mais desejar, mais penar, menos desejar, menos penar; nenhum desejo, eliminado o

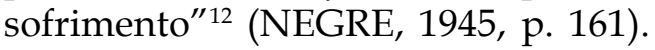

Retomando: a autonegação da vontade não é um acontecimento universal, pelo contrário, é individual. Constitui-se numa recusa do princípio de individuação e do egoísmo dele derivado. A salvação ${ }^{13}$ é estranha à nossa personalidade. A

${ }^{12}$ Maiores informações sobre a doutrina budista ver: NEGRE, P. S. J. Budismo enigmas de un Nirvana misterioso. Barcelona: Labor, 1945.

${ }^{13}$ Ver ÁVILA, R. Pesimismo y filosofía en A. Schopenhauer. Pensamiento. Madrid, n. 177 , v. 45, p. 69, enero/marzo, 1989. O autor revela que as possibilidades de salvação apontadas por Schopenhauer não constituem um caminho por onde pode transitar a maioria dos homens. Ver, também, LÓPEZ, P. Voluntad y 
condição sine qua non para libertação da escravidão da vontade é a renúncia da individualidade, da personalidade. A própria arte, primeira possibilidade de libertação da vontade, requer um esquecimento da personalidade. Na contemplação estética, o gênio perde sua individualidade ao se fundir com o objeto. Cabe-nos dizer que existem três possibilidades de salvação, desde que a inteligência libertou-se do serviço da vontade e passou a considerar a própria essência do universo. A primeira constitui-se na satisfação da necessidade estética por meio do estado de contemplação pura. A segunda forma é representada pela necessidade moral por intermédio do princípio da compaixão. A última possibilidade, ou o autêntico remédio contra a dor da vida, não pode ser outro senão a negação da vontade. ${ }^{14}$

Devemos ressaltar que essa negação da vontade não constitui um enfrentamento físico como um suicídio, por exemplo, mas uma negação que se dá por via do conhecimento.

O suicídio, segundo Schopenhauer "[...] é uma marca de afirmação intensa da Vontade, visto que a negação da Vontade consiste, não em ter horror aos males da vida, mas em detestar-lhe os prazeres" (MVR, s./d., p. 528). A negação da Vontade não se constitui como um simples não à vida, mas antes como uma possibilidade do conhecimento metafísico.

nihilismo en A. Schopenhauer. Pensamiento. Madrid, n. 175, v. 44, p. 268, julio/ sep. 1988. Em confluência com Ávila, López afirma que as saídas propostas por Schopenhauer exigem uma consciência genial, não constitui uma possibilidade para o homem vulgar. Nós percebemos a saída estética como elitista porque pressupõe uma genialidade. Quanto à saída ética, apesar de ter por princípio um sentimento, a compaixão, fundamenta-se na verdade metafísica da unidade radical entre os seres. Sendo que a percepção dessa verdade exige um conhecimento superior que não é, necessariamente, acessível a todos os homens.

${ }^{14}$ Ver ÁVILA, R. Pesimismo y filosofía en A. Schopenhauer. Pensamiento. Madrid, n. 177, v. 45 enero/marzo, p. 60, 1989. O comentador chama atenção para o fato de que o fundamento do nihilismo é o pessimismo. Todo o esforço para se libertar do sofrimento da existência é malogrado, exceto a redenção da existência pela aniquilação da vontade. Em Schopenhauer "o pessimismo é a ante-sala do nihilismo". 
Surge, aqui, um problema difícil: a relação entre a vontade e o conhecimento. Para Schopenhauer, o saber abstrato, racional, responsável pelas grandes criações humanas como o estado, a linguagem, as leis e as ciências é inócuo quando trata-se do conhecimento da essência do universo. A razão dá conta do mundo fenomênico, da rede causal entre os objetos deste mundo. A reflexão sobre a coisa-em-si, ou seja, a Vontade, escapa aos domínios da razão. Apenas por meio do conhecimento intuitivo é que as últimas verdades filosóficas serão desvendadas. Constituirá uma tarefa para a filosofia traduzir em saber abstrato estas verdades filosóficas reveladas a cada homem através do conhecimento intuitivo. Nas palavras de Schopenhauer:

Traduzir a essência do universo em conceitos abstratos, universais e claros, dar deles uma imagem refletida mais estável, sempre à nossa disposição e que reside na razão, eis tudo o que a filosofia deve fazer (MVR, s./d., p. 510).

A percepção da identidade radical entre os seres, ou seja, a ultrapassagem da ilusão do princípio da individuação - condição de possibilidade para a moralidade e para a negação da vontade resulta do conhecimento intuitivo. A razão ou o saber abstrato não dissipa o véu do princípio da individuação, pelo contrário, o saber racional alimenta-se da manifestação particular e individual dos seres. O conhecimento racional ou abstrato apóia-se no entendimento, e este, por sua vez, opera segundo as formas puras do tempo e espaço, e através da lei da causalidade, sendo que a principal conseqüência da combinação entre esses três elementos (tempo, espaço e causalidade) será o princípio de individuação. Assim Schopenhauer nos diz que o conhecimento que resultam da negação da vontade, da conduta moral e da criação artística é intuitivo e não abstrato, por isso nos conceitos abstratos não encontraremos a perfeita expressão e elucidação desses enigmas; apenas a ação, a conduta desvelará o segredo. Dessa forma, se quisermos compreender melhor, ou seja, em termos filosóficos, a negação da vontade e a moralidade, teremos que procurar exemplos 
na experiência. Schopenhauer não está propondo um trabalho de pesquisa empírica, apenas está alertando para o fato de que a fonte primordial da reflexão filosófica é a própria experiência. Esse momento do texto schopenhaueriano é rico de citações biográficas. Schopenhauer refere-se à vida de Cristo, de São Francisco de Assis, de Buda, Madame Guyon e outros heróis da humanidade.

Mas, ainda que não seja possível explicar precisamente, ou melhor, racionalmente a negação da vontade, Schopenhauer mantém sua identidade de filósofo, tentando traduzir em saber abstrato e submeter à reflexão o mistério da negação da vontade. Schopenhauer dirá, primeiramente, que a negação da vontade é o caminho mais eficaz para a libertação e salvação do sofrimento, para a libertação da escravidão da vontade insaciável. A negação da vontade constitui, em última instância, uma experiência vivida, uma dimensão positiva, podemos dizer que é um estado de iluminação. Como já foi mencionado, esse estado de iluminação não pode ser alcançado pelo conhecimento racional, pois esse está preso no princípio da individuação. Existem duas maneiras de alcançar esse conhecimento ou iluminação: primeiro, pelo conhecimento que se tem do sofrimento inerente à Vontade, conhecimento este intuitivo; segundo, pela dor diretamente sentida. A primeira via de acesso à negação da vontade é mediada pelo conhecimento intuitivo. Graças à intuição percebemos que o princípio da individuação é uma ilusão e mais, que este princípio é responsável pelo egoísmo e, conseqüentemente, pelas condutas antimorais. Mas, sobretudo, percebemos que a dor é a própria essência da vontade, que o sofrimento é inerente ao querer. Por esse caminho, ou seja, via conhecimento, "chegando a conhecerse a si mesma, a vontade de viver afirma-se; depois nega-se" (MVR, s./d., p. 355). Parece-nos que este primeiro caminho para a verdadeira salvação e libertação efetiva da vida e da dor requer uma consciência elevada. É preciso ultrapassar os obstáculos ao crescimento, como o egoísmo, a avidez, a maldade, a injustiça e, principalmente, a ilusão do princípio de individuação. Talvez, para uma consciência pouco evoluída, o caminho mais indicado para a libertação e salvação seja a imediata negação da vontade, que 
acontece através da dor sofrida diretamente. Pelo caminho do sofrimento, da aflição crescente o homem pode chegar à liberdade e salvação. Segundo Schopenhauer: “[...] é quase sempre preciso que grandes sofrimentos tenham quebrado a vontade para que a negação do querer se possa produzir" (MVR, s./d., p. 520).

Nesse ponto, Schopenhauer não parece privilegiar o homem santo em relação ao criminoso, pois os dois podem participar do mesmo impulso que conduz à redenção definitiva. É possível que o homem santo esteja mais próximo da redenção, mas também é possível que um golpe de sorte ofereça ao criminoso a redenção tão esperada pelo santo.

Um grande sofrimento ou uma grande infelicidade revela-nos o último segredo da vida, pois nos faz compreender a inutilidade de nossos esforços em manter o princípio de individuação. Todos os pequenos desejos egoístas do ser humano são eclipsados diante da dor da morte de um ente querido, ou diante da iminência de nossa própria morte. Contudo, devemos enfatizar que esse conhecimento que produz a negação da vontade não é definitivo. Em breve, a ilusão das aparências nos envolve, permitindo que caiamos novamente na tentação do movimento dos desejos. Devemos reconquistar a paz através de perpétuos combates.

A discussão sobre a negação da vontade propicia a retomada do tema da liberdade. A liberdade propriamente dita, isto é, a independência do princípio de razão é uma exclusividade do mundo numênico, pois a lei da causalidade é forma essencial do mundo fenomênico. A única possibilidade da inclusão da liberdade no mundo fenomênico, ironicamente, marca a negação desse mesmo mundo. A liberdade só é possível depois que se nega a vontade, ou as manifestações individuais da vontade. Não podemos deixar de ressaltar que a retomada da possibilidade de liberdade é urgente, pois sem esta discussão a ética carece de sentido e de verdadeiros destinatários.

Cabe, ainda, uma última consideração: Schopenhauer utilizase da distinção kantiana entre nihil negativum e nihil privativum. A negação da vontade que tratamos aqui configura-se como uma negação relativa, algo da ordem do nihil privativum. A negação 
absoluta inscreve-se no âmbito das coisas não comunicáveis. Schopenhauer recusa a existência do nada absoluto, pois este não pode ser pensado. Esta distinção é importante, pois neutraliza a seguinte objeção: ${ }^{15}$ sendo a Vontade a coisa-em-si, como poderia ser negada? Schopenhauer não está propondo uma negação absoluta da Vontade, mesmo porque esta encontra-se fora do princípio da razão. Deve-se negar a manifestação fenomênica da Vontade. Para além desta resposta, podemos citar Palao (1990, p. 221), que revela a negação da vontade como uma positividade, pois, na verdade, é a negação de uma autocontradição da vontade. A negação constitui um retorno da identidade da vontade consigo mesma. Uma reconstrução da identidade, neste sentido, a supressão de uma demência, a volta à unidade.

Assim, a verdadeira felicidade e liberdade encontram-se na negação da vontade, pois neste estado não se tem mais a sede furiosa da vontade e nem o triste espetáculo das inúmeras frustrações. Na renúncia voluntária, encontraremos paz, calma e serenidade, ou seja, o verdadeiro reduto da alegria. Urge dizer que a libertação da vontade é um privilégio humano. $O$ animal é completamente incapaz de liberdade, pois neste a vontade não chega a conhecer a si mesma.

Não seria impertinente realizar uma pequena discussão sobre o estatuto da Vontade na filosofia de Schopenhauer. Consideramos a Vontade como um recurso crítico e um dispositivo antidogmático. O dogmatismo ${ }^{16}$ tradicionalmente atribuído a Schopenhauer

${ }^{15}$ Ver: CACCIOLA, M. L. Schopenhauer e a questão do dogmatismo. São Paulo: EDUSP, 1994, p. 24. A autora cita a objeção de Frauenstädt de que a Vontade, sendo coisa-em-si, não poderia ser negada. E a resposta de Schopenhauer que nega a qualidade de absoluto para a Vontade, a Vontade é coisa-em-si em relação à representação.

${ }^{16}$ Rubens Rodrigues Torres Filho no Prefácio do livro de Maria Lúcia Cacciola comenta que a autora irá trabalhar com a questão do dogmatismo de Schopenhauer, modelo interpretativo, e com a questão do dogmatismo segundo Schopenhauer, modelo historiográfico. Com esta dupla referência é possível refletir sobre o dogmatismo atribuído a Schopenhauer - a Vontade como o emsi do Mundo - e o dispositivo antidogmático de Schopenhauer figurado pela crítica deste filósofo às ilusões metafísicas. 
refere-se a esta questão da doutrina da Vontade como um em-si, pensando nesta doutrina como um princípio que se impõe, que não é colocado em questão. Mas Schopenhauer sustenta a posição diante de seu discípulo Frauenstädt ${ }^{17}$ de que a Vontade só é em-si em relação à representação, ou seja, em relação ao fenômeno. Para Schopenhauer, podemos falar da coisa-em-si somente em relação ao fenômeno, e vice-versa. O que é a Vontade para além dessa relação não é possível saber. Schopenhauer, numa tentativa de criar um dispositivo antidogmático, propõe pensar o mundo sobre duas perspectivas: o mundo como Vontade e o mundo como Representação. Parece que a afirmação de Nietzsche ${ }^{18}$ de que Schopenhauer apropriou-se da filosofia kantiana como um "extraordinário instrumento de retórica" segue a mesma linha de raciocínio que considera a Vontade apenas como um ponto de vista e não uma res. A Vontade não aparece em Schopenhauer como um fundamento ontológico, não é um absoluto, mas sim um ponto de vista, um Standpunkt. Mas, diante da problemática moral, uma questão surge. A perspectiva moral schopenhaueriana, que está fundamentada na percepção da unidade radical entre os seres, não exigiria uma consideração da Vontade como fundamento último? Em outras palavras, considerar a Vontade meramente como um ponto de vista, que possui uma função crítica para o conhecimento, apontado para o limite, não acarretaria um enfraquecimento da perspectiva moral? Schopenhauer não deixa dúvidas. Sua resposta à objeção de Frauenstädt revela que a Vontade não é um em-si, não possui uma qualidade absoluta, por isso pode ser negada. Em nossa resposta à objeção de Frauenstädt diríamos que não há contradição no processo de negação da vontade porque a negação recai sobre a manifestação fenomênica

${ }^{17}$ Sobre a discussão da Vontade como um em-si ou um instrumento crítico ver nas Correspondências a resposta de Schopenhauer para Frauenstädt, p. 290 (24/8/1852). Citado por CACCIOLA, M. L. Schopenhauer e a questão do dogmatismo. São Paulo: EDUSP, 1994, p. 24.

${ }^{18}$ NIETZSCHE, F. Schopenhauer como educador (1874). In: Considerações extemporâneas. São Paulo: Abril Cultural, 1991, p. 42. (Coleção Os Pensadores). 
da Vontade. É uma negação do múltiplo e uma afirmação da unidade da Vontade. A negação pode ser definida como um retorno da unidade à Vontade. Entretanto nosso problema permanece: Como manter toda a densidade da problemática moral e da necessidade de um fundamento metafísico sem cair no dogmatismo da consideração da Vontade como um em-si? Podemos manter a perspectiva da Vontade como um fundamento; a condição é não esquecer o caráter de atividade da Vontade. A Vontade não é uma res, é uma pulsão, uma ação. Schopenhauer revela: "Todo o ato real da nossa vontade, é, ao mesmo tempo, e infalivelmente, um movimento do nosso corpo [...]" (MVR, s./d., p. 133). Há uma identidade entre o ato voluntário e a ação do corpo. "A ação do corpo é apenas ato de vontade objetivado, isto é, visto na representação" (MVR, s./d., p. 133).Toda ação reflete a essência do universo, a Vontade. Entretanto, no domínio humano, existe uma ação que pode espelhar com perfeição a Vontade, a saber, a ação moral. Entre o ato moral e a Vontade, ou melhor, a atividade da Vontade, não há relação causal, há uma relação de identidade.

Parece-nos que, dentro do âmbito da moralidade, não podemos considerar a Vontade apenas como um ponto de vista, que desempenha uma função crítica, mas também como um princípio metafísico. Um princípio referencial que desenha um horizonte crítico em que se torna possível avaliar a conduta moral.

\section{Bibliografia primária}

SCHOPENHAUER, A. (1819). O mundo como vontade e representação. Tradução de M. F. Sá Correia. Porto: Rés, s.d.

(1941A). Sobre o fundamento da moral. Tradução de Maria Lucia Cacciola. São Paulo: Martins Fontes, 1995.

(1819/44). Crítica da filosofia kantiana. Tradução de Maria Lúcia Cacciola. São Paulo: Abril Cultural, 1988. (Coleção Os Pensadores). 


\section{Bibliografia secundária}

ÁVILA, R. C. Pesimismo y filosofia en A. Schopenhauer. Pensamiento, Madrid, v. 45, n. 177, p. 57-75, enero/marzo. 1989.

CABADA, M. C. La reflexion sobre la negacion o afirmacion de la vida en Schopenhauer, Feuerbach, Wagner y Nietzsche. Pensamiento, Madrid, v. 47, n. 188, octubre/diciembre. 1991.

CACCIOLA, M. L. Schopenhauer e a questão do dogmatismo. São Paulo: Edusp, 1994.

ELÓSEGUI, M.I. La simpatía y la solidaridad. Una confrontacion entre Schopenhauer y Bergson. Pensamiento, Madrid, v. 45, n. 177, p. 77-86, enero/marzo. 1989.

HERRERO, F. J. Sujeito e ética. Kriterion, Belo Horizonte, n. 88, p. 87-97, ago./dez. 1993.

KANT, I. Fundamentação da metafísica dos costumes. São Paulo: Abril Cultural, 1974. (Coleção Os Pensadores).

. O belo e o sublime (ensaio de estética e moral). Tradução de Alberto Machado Cruz. Porto: Livraria da Educação Nacional, 1942.

LÓPEZ, P. S. M. Voluntad y nihilismo en A. Schopenhauer. Pensamiento, Madrid, v. 44, n. 175, p. 257-278, julio/septiembre, 1988.

MOREIRA, Jacqueline de Oliveira. A negação da vontade: o problema da fundamentação da moral na filosofia de Schopenhauer. 1996. 172 p. Tese (Doutorado em Filosofia). Universidade Federal de Minas Gerais, Belo Horizonte, 1996. 
NIETZSCHE, F. Schopenhauer como educador (1874). In: Considerações extemporâneas. São Paulo: Abril Cultural, 1991. (Coleção Os Pensadores, Obras Incompletas).

PALAO, A. La sabiduria del vacío. In: URDANIBIA, J. (Coord.). Os antihegelianos: Kierkegaard y Schopenhauer. Barcelona: Anthropos, 1990, p. 211-237.

PERNIN, Marie-José. Schopenhauer [1992]. Rio de Janeiro: Jorge Zahar, 1995.

ROGER, A. Prefácio. In: SCHOPENHAUER, A. Sobre o fundamento da moral. São Paulo: Martins Fontes, 1995, p. LVII.

Data de Registro 23/05/06 Data de Aceite 03/07/06 